https://helda.helsinki.fi

Mobile lives, immutable facts : family reunification of children in Finland

\title{
Tapaninen, Anna-Maria
}

2019-04-04

Tapaninen , A-M , Halme-Tuomisaari , M \& Kankaanpaa , V 2019 , ' Mobile lives, immutable facts : family reunification of children in Finland ' , Journal of Ethnic and Migration Studies, vol. 45 , no. 5 , pp. 825-841 . https://doi.org/10.1080/1369183X.2017.1405725

http://hdl.handle.net/10138/326189

https://doi.org/10.1080/1369183X.2017.1405725

acceptedVersion

Downloaded from Helda, University of Helsinki institutional repository.

This is an electronic reprint of the original article.

This reprint may differ from the original in pagination and typographic detail.

Please cite the original version. 


\section{Mobile lives, immutable facts: family reunification of children in Finland}

\section{Anna-Maria Tapaninen, Miia Halme-Tuomisaari \& Viljami Kankaanpää}

To cite this article: Anna-Maria Tapaninen, Miia Halme-Tuomisaari \& Viljami Kankaanpää (2017): Mobile lives, immutable facts: family reunification of children in Finland, Journal of Ethnic and Migration Studies, DOI: 10.1080/1369183X.2017.1405725

To link to this article: https://doi.org/10.1080/1369183X.2017.1405725

曲 Published online: 23 Nov 2017.

Submit your article to this journal $\pi$

Q View related articles $\sqsubset$

View Crossmark data \lceil 


\title{
Mobile lives, immutable facts: family reunification of children in Finland
}

\author{
Anna-Maria Tapaninen (D) a , Miia Halme-Tuomisaari ${ }^{\mathrm{a}, \mathrm{b}}$ and Viljami Kankaanpää ${ }^{\mathrm{a}, \mathrm{c}}$ \\ ${ }^{a}$ Department of Social Sciences, University of Eastern Finland, Joensuu, Finland; ${ }^{b}$ Genève Graduate Institute, \\ Geneva, Switzerland; 'Department of Social Sciences, University of Helsinki, Helsinki, Finland
}

\begin{abstract}
The right to family has been confirmed by myriad human rights covenants and it forms an acknowledged part of migration policies. Yet family reunification has become an increasingly contested issue, something reflected in a recent restrictive turn in migration policies throughout Europe. Policy reforms speak of a growing polarity between, on the one hand, adherence to the 'best interest of the child' and family life, and on the other, suspicion of fraud. This article examines these tensions via exploration of family reunification procedures in Finland, particularly applications sponsored by minors, thereby drawing attention to the notion of 'the anchor child'. Drawing on decisions by the Administrative Court of Helsinki as well as interviews with experts and the people concerned, the writers discuss how these polarities are managed in practice, centring their analysis on a quest for truth that deploys various methods, particularly DNA analysis and oral hearings. Ultimately the article highlights an intrinsic paradox in family reunification policies that incorporates the aspiration to produce facts amounting to 'immutable mobiles' (Latour, Bruno. 1986. 'Visualization and cognition: Thinking with the eyes and hands.' Knowledge and Society 6 (6): 1-40.) and the evident weight of contingent temporalities.
\end{abstract}

\section{ARTICLE HISTORY}

Received 3 July 2017

Accepted 3 November 2017

\section{KEYWORDS}

Family reunification; underage sponsors; DNA; time; Finland

\section{Introduction}

For time is the longest distance between two places. (Tennessee Williams)

'Time is on our side', noted a police officer dryly in an interview regarding family reunification procedures. Time was not supposed to be something that preoccupied us, either in this interview or in our broader project, which deals with the interplay of different forms of evidence in family reunification procedures; namely, documents, narratives in interviews and biotechnologies, particularly DNA analysis. Yet, inevitably, different temporalities started to dominate our analysis. The passing of time is structured by legal and administrative requirements, on the one hand, and by the precarious routes of people aspiring to be reunited with their kin, on the other. Time is both fixed and inequitable. As the official observed, only one side - the 'us' of decision-makers - stood to benefit from its passing. In this article, we examine this reality via Finnish family reunification applications sponsored 
by minors. For these children and their families, time plays a role of particular importance. While family reunification processes are supposed to be steered by the notion of the best interest of the child, they are inhabited by suspicion of deceit. We examine the dynamics of doubt and proof (Good, Berti, and Tarabout 2015) via the pejorative term 'anchor child', which refers to minors who are sent to Finland to seek asylum and to eventually sponsor family reunification applications for the remaining family members.

The definition of family members is relatively inclusive in the Finnish Aliens Act (see Heinemann, Naue and Tapaninen 2013). In addition to the minor's guardians, also his or her 'de facto guardians', i.e. foster parents, can be eligible. Section 52 states the if the minor has received a residence permit on the basis of compassionate grounds, his or her minor siblings can be issued with a residence permit if the children have lived together and 'the parents are dead or their whereabouts are unknown'. In addition, the children do not have to have secure means of support. Despite the liberality of the provisions, the alleged 'anchor children' seldom get their family members to Finland, as our article demonstrates. Our analysis articulates the prevalence of distrust towards the applicants' claims and illustrates how it is played out in the search for - and making of - reliable evidence of true family ties.

This article focuses on the role of time in family reunification, particularly the role it fulfils in the interplay of personal narratives and DNA analysis. Our research brings together two incommensurate variables: the utterly abstract evidence of DNA analysis and the actual, complicated unfolding of kinship relations over time. Here this article continues our earlier analysis on the indeterminacy of migration proceedings (Halme-Tuomisaari, Tapaninen, and Aunela n.d.). While migration has predominantly been studied as a movement in space, recently the temporalities of migration have been discussed in the context of the predicament of refugees en route (Khosravi 2007, 2010; Feldman 2011; Andersson 2014b), asylum seekers (Cabot 2012; Griffiths 2014; Kelly 2015) and migration at large (Cwerner 2010; Griffiths, Rogers, and Anderson 2013).

Meanwhile, the question of time has largely been bypassed in the study of DNA analysis for family reunification, which has mainly been approached from the perspective of legal studies, highlighting discussions of the 'biological' versus 'social' definitions of families (Taitz, Weekers, and Mosca 2002; Murdock 2008; UNHCR 2008; Esbenshade 2010; Villiers 2010). This binary has also been framed as the geneticisation of the family (Heinemann and Lemke 2013, 2015). Another question has concerned the ethical implications of compulsory testing (Villiers 2010; Weiss 2011; Dove 2013; Holland 2014). Recently, DNA analysis for family reunification has also been scrutinised as a specific form of biological citizenship (Heinemann and Lemke 2014; Helén 2014). Despite technical similarities, the role of DNA analysis varies considerably between countries, which has been examined in comparative studies (La Spina 2012; Heinemann, Naue and Tapaninen 2013; Heinemann et al. 2015).

While this corpus of research has offered new perspectives on how biopolitics is embedded in migration policies, the analysis has tended to be fixed at a general level. It is as if the static basis of DNA analysis were replicated in the argumentation. We aim to go further - or, rather, closer - to the actual practices of creating and reading the fragments of proof, instead of deciphering DNA testing in the abstract. We thus ask: what could DNA profiling do in the verification of family ties? And further, what role does time play in the outcome of such profiling? 
These questions emerge from the realisation that in Finnish migration proceedings DNA evidence is neither a necessary nor a sufficient piece of evidence in itself (Helén and Tapaninen 2013; Tapaninen and Helén 2015; Halme-Tuomisaari, Tapaninen, and Aunela n.d.). The Aliens Act does not explicate the role of DNA analysis in decisionmaking. Pursuant to Section 65,

The Finnish Immigration Service may provide an applicant or sponsor with an opportunity to prove their biological kinship with DNA analysis paid from State funds if no other adequate evidence of family ties based on biological kinship is available and if it is possible to obtain material evidence of the family ties through DNA analysis.

To shed light on this uncertainty, Because of this uncertainty, we look at the potentials and limits of DNA evidence.

In our analysis, we build on Latour's (1986) work on inscriptions, particularly the manner that they function as 'immutable mobiles'. By this he refers to the making of objects that are not only mobile but also immutable, readable and combinable. In inscriptions, for example in maps, the objects studied are simplified and made flat. DNA analysis is an allegedly objective inscription mobilising and summarising the complex phenomenon of family ties. However, we also discuss how objectivity and precision come to be challenged, and how suspicion thus becomes embodied in detail and the unexpected.

\section{Methodology}

An approach investing its focus on temporality gains its importance from the realisation that the standards of DNA analysis strip the make-up of families from anything related to time - a significant abstraction considering that the passing of time is of paramount importance for people on the move. This tension has led us to look at the ways the two dimensions come together: the immutable mobile of DNA analysis and the vicissitudes of time in migration. We place the utterly abstract results of DNA profiling in context by paying close attention to the contingent unfolding of time. Our data make possible a nuanced picture wherein the significance of DNA testing is mobile. We have examined the dynamics and tensions of family reunification on the basis of decisions made between 2003 and 2014 by the Administrative Court of Helsinki containing the word DNA, totalling 253 cases. In this article, we focus on the 41 cases sponsored by minors. We have built our sample around the keyword DNA not because we want to understand the reasons for and consequences of DNA testing for family reunification, but rather in order to examine the interplay of different forms of evidence. We believe that approaching immigration management through DNA testing can shed light on the dynamics of doubt and proof in general.

These court decisions offer glimpses of the stakes and tensions involved, which we contextualise further via our interviews with experts and the people concerned. Even though the interests of our interlocutors differ greatly, they all focussed on the question of credibility. Many officials emphasise the complicated maze of kinship ties in the applications. They also tend to stress, defensively, the legal framework directing their decisions. The attorneys and the people working in NGOs highlight the inexplicable bureaucratic obstacles and the hardship and despair of their clients. The people concerned can be utterly perplexed about the reasons for rejections. When we interviewed five Finnish 
Somalians whose applications for family reunification had been rejected, they expressed their frustration in unison by pointing out that the Finnish Immigration Service should plainly state in its web pages: 'You will not get your family to Finland'. The cases we have examined largely confirm this: it is hard, often impossible, to convince the authorities of the merits of the cases.

We attempt to gain further clarity by looking at the multiple contradictions at play in the quest for truth. First, there is an evident tension between the most precise pieces of evidence created, exemplified by DNA analysis, and the ambiguity of interpretations. This was spelled out in a press release by the Finnish Immigration Service in 2008: 'A purely biological relationship is not, however, sufficient for a positive decision without a background of a genuine, permanent family life' (Finnish Immigration Service 2008, emphasis added). Thus, the temporal dimension is inserted into the verification of stable family ties, and interviews are therefore the primary method of investigation. We argue that DNA profiling provides the model for the making of objective facts by other means, too, particularly through oral hearings. In the process, the 'facts' produced via the technologies of doubting (see Good, Berti, and Tarabout 2015) function as immutable mobiles (Latour 1986).

Second, the ambiguity of interpretation also has a temporal aspect. The analysis of genetic relatedness is detached from time altogether, but families are not reunified in or through laboratories. The multiple temporalities play a decisive role, which we analyse by examining the interplay and paradoxes between the bureaucratic time of control and the time of migration (Andersson 2014b). The duration of the process is structured by the legal framework and the meticulousness of investigations. For the migrants, time entails duration in the form of 'stuckedness' (Hage 2009; Cabot 2012, 2014) or 'stasis' (Griffiths, Rogers, and Anderson 2013). Time also weighs in heavily in the oral hearings that aim at substantiating the immutability and permanence of family life through narrative minutiae despite the long separations.

We begin our article by deciphering the emergence and persistence of the problem of 'anchor children' in Finland. Next, we discuss, following Latour's (1986) idea of immutable mobiles, the making of evidence. This is followed by a description of our data, of the chaotic circumstances in which the quest for objective truth is carried out. Finally, we foreground the unfolding of tensions by analysing the contrasting yet closely related progression of bureaucratic time and migratory time.

\section{'Anchor children' and the Finnish immigration policies}

'Once upon a time there was a little anchor child', headlined a politician of the populist Finns' Party in a triumphant blog post in 2009. The text was triggered by a decision of the Supreme Administrative Court (KHO:2008, 86) that upheld a rejection by the Finnish Immigration Service of an application for family reunification sponsored by a small Somali child, identified as A. He had been sent to Finland at the age of two in 2004, was living with his uncle's family and had received a residence permit on compassionate grounds in 2005. The following year he - or, rather, his guardian - had applied for family reunification to be united with his parents and two younger siblings. This decision was a precedent for similar cases: applications sponsored by children who had come to Finland as unaccompanied minors. They were and are still known by the pejorative term 'anchor child'. 
The decision by the Supreme Administrative Court encapsulated the momentous debate over the children's right to family and the perceived threats of family reunification, juxtaposing abuse of the system with the abuse of children.

This decision gave further impetus to the restrictive turn in legislation and administration. By the time of the rejection, the term 'anchor child' had already become an established part of migration vocabulary in Finland ${ }^{1}$ (see Horsti and Pellander 2015) especially within the potent anti-immigration rhetoric - and a 'phenomenon' notoriously framed through the problematic of ubiquitous fraud. It had already been concluded in 2004 in the Administrative Committee of the Finnish Parliament (HaVM 4/2004) that a child should not be used as 'an instrument of immigration'. It was believed that preventing this would be 'in the best interest of the child' although the parents 'may try and safeguard the child's life'. This stand justified the aforementioned decision, and, as we will show, subsequent decisions as well. In A's case, the Court details that his father had 'forthrightly said that the purpose [of sending the child] was that he could file an application to help his family'.

The debate did lead to legislative changes that materialised in the amendments to the Aliens Act in 2010 (539/2010) that focused on family reunification of minors in particular. The provisions on medical age assessment were incorporated in Article 6b. The consequences of age analysis can have serious circumstances, because pursuant to the amended Section 6(3) of the Aliens Act, the child also has to be underage at the time the decision is made and not only when the application is filed. Furthermore, Article 37 specified the criteria applied in the case of 'de facto guardians', that is, foster parents, which had triggered another momentous debate in Finland during the same years. ${ }^{2}$ Claiming family reunification on the basis of fosterage is largely perceived to be fraudulent. Of special relevance for the cases we examined is Section 36 (3) that stipulates the sanctions for fraudulent claims. It reads:

A residence permit by reason of family ties may be refused if there are reasonable grounds for suspecting that the sponsor has received a residence permit by circumventing the provisions on entry or residence by providing false information on his or her identity or family relations.

How can false information on family ties be uncovered? What makes grounds for suspicion reasonable? We will answer these questions throughout the article.

The question of anchor children has been framed via the rhetoric of the war on the trafficking of vulnerable children. In fact, the Finnish Immigration Service (Maahanmuuttovirasto 2013 , 5) has explicitly stated that 'family reunification is not necessarily in the best interest of the child', and therefore it is easier for a parent to sponsor the application than for the child. The memorandum also directly linked the problem of unaccompanied minors to the above-mentioned circumvention of the provisions.

Statistics provide evidence of the consequences of this line of reasoning. The duration of the process is exceptionally long in the case of guardians of children who are under international protection; in 2016, it took 325 days on average (Maahanmuuttovirasto 2017). While the success rate of family reunification applications sponsored by minors was estimated to have been $80-85 \%$ around the turn of the decade (EMN 2011, 64-5), the current numbers indicate the consequences of the new restrictive turn. In 2013, of the 157 guardians in cases involving minors, only one was granted a residence permit (Maahanmuuttovirasto 2014). In the following years, around one quarter of guardians did succeed, but 
the number of applications had dropped dramatically. ${ }^{3}$ Furthermore, our data show that the Administrative Court seldom revokes the rejections: of the 41 cases, only six were returned to the Finnish Immigration Service.

\section{The making of immutable mobiles}

The current restrictive turn has also changed the role of DNA analysis. Importantly, the introduction of DNA testing in Finland in the 1990s was justified by the problem of unaccompanied minors who were separated from their families (Helén and Tapaninen 2013; Tapaninen and Helén 2015). The availability of DNA testing was considered to be in the best interest of the child. In our analysis, we ask how the question is tackled now, two decades after the instigation of DNA testing. It is obvious that a fundamental and strangely coherent change has taken place.

To contextualise this query, a brief look at DNA evidence for family reunification is useful. In short, in the absence of documents such as birth and marriage certificates that are accepted by the authorities, applicants, particularly those with a refugee background, have to prove their family ties via interviews and, most likely, DNA analysis. In at least 24 countries of the Global North, DNA testing has become an established method in the managing of family reunification (see EMN 2009; Heinemann et al. 2015; EMN 2016). Yet, despite the widespread use of DNA analysis for family reunification, legislative frameworks and practices vary considerably between countries (see Taitz, Weekers, and Mosca 2002; Murdock 2008; EMN 2009; Villiers 2010; La Spina 2012; Dove 2013; Holland 2014). DNA testing has spread from country to country between somewhat nebulous areas, where the actual purposes and weight of DNA testing is elusive and subject to fluctuations in response to changing immigration policies. It is one response to the ubiquitous suspicion which frames the debate on family reunification at large. The uncovering of fraudulent claims has also prompted the production of numerous studies by the European Migration Network (e.g. EMN 2011, 2012). Throughout Europe, policies are driven by the dynamics of ubiquitous doubt and reliable proof, calling for the use of increasingly efficient biogenetic and biometric tools. It is evident that 'doubt is at once a property and product of the system' (Whyte 2015, 141). Among the methods, ranging from fingerprinting to medical age assessment and language analysis, DNA analysis for family reunification stands out because of its perceived accuracy.

Since the provisions for DNA testing were incorporated into the Finnish Aliens Act in 2000, it has largely become routine: the legislation has remained unaltered, the division of labour between the authorities is well established, and the practice of testing has mostly been uncontested (Helén and Tapaninen 2013; Tapaninen and Helén 2015). Compared to many other countries, the system of parental testing in Finland is legalistic and centralised (Heinemann, Naue and Tapaninen 2013; see also Taitz, Weekers, and Mosca 2002; EMN 2009; La Spina 2012; Heinemann et al. 2015). Of particular relevance is the fact that DNA testing is offered to the people concerned by the Finnish Immigration Service at the expense of the state. In fact, the applicants and sponsors cannot even organise or demand testing themselves, which partly explains the numerous appeals to the Court wherein DNA is mentioned.

Yet, despite its seeming ability to offer uncontested 'facts' about relatedness and family ties, the role played by DNA evidence in family reunification cases is uncertain, as the 
debate on anchor children illustrates. Evidence as a whole is a collection of inscriptions. The decisions of the Administrative Court are based on the decisions of the Finnish Immigration Service and on the folders of documents submitted with the applications and appeals that can contain a plethora of various kinds of material evidence: letters, family photos, the statements of doctors, teachers and social workers, receipts of money transfers and flight tickets and, above all, the minutiae of interviews. The inscriptions are built on the layered creation of evidence over a long period of time, with numerous authors, subjects, contexts, languages and registers.

Following Latour (1986), we saw that the inscriptions are akin to 'immutable mobiles'; like documents, they are fixed, and like maps and graphs, they are mobile as they can travel between different authorities, span space and time and be combined with other inscriptions and other forms of information. DNA evidence is but one element in the intricate logic of decision-making where incommensurate 'facts' are brought together and 'averaged out' or 'made flat' (Latour 1986), thereby making those crossing the borders legible (see Scott 1999). This is obvious in the case of DNA evidence; the reports have the appearance of immutable mobiles par excellence: they can be visualised, formulated and flattened via numbers, and they refer to the unchangeable genetic make-up of the people giving the samples. These 'facts produced out of human tissue' (M'charek 2000, 137) are converted into numbers, which allegedly provide objective and accurate proof. The body can thus be made 'readable' by translating it into digital code and information (van der Ploeg 1999). Migrants are among those suspected or feared for being 'unidentified, unidentifiable or 'identity-less'..., whose minds cannot be trusted but whose bodies do not lie'(Aas 2006, 156).

M'charek (2000) elegantly shows that in the context of criminal investigations in the Netherlands not even DNA profiles are absolute or actually immutable but, together with the matching likelihood numbers, are open to contestation and reinterpretation. Nevertheless, they do offer the illusion of precision. Even though other forms of evidence, such as the minutiae of narratives, are not as precise, they can be read in a similar vein. Selected traces of standardised interviews are summarised and thereby also radically transformed when they move from the hearings at embassies or police stations to the Finnish Immigration Service. We argue that the availability of the allegedly objective proof of DNA testing becomes the standard of 'truth' to the extent that all other created evidence, for example, the details of interviews, aims at uncovering inconsistencies and, by the same token, fraud. Suspicion takes form in 'detailed and unexpected questions' (Maahanmuuttovirasto 2013, 9) in successive interviews. The interviews, too, seek immutable, precise facts.

Yet the interviews are not recorded and the methods of interviewing, especially in the case of children, are questionable. The 'facts' are produced through multiple translations, literally and figuratively, that are also unavoidably open to interpretation (Kelly 2012; Carver 2014; Gibb and Good 2014). In this assemblage, the authorship of the interviewees is limited. The legal representatives often request an oral hearing in front of the Court but just as routinely, without exception, the request is declined. One lawyer explained that she insists on this possibility because meeting the child face to face could lead to a more humane approach, giving the child the only chance to explain the discrepancies in her or his favour. Instead, the decisions are based solely on detailed yet incommensurate inscriptions. Below we argue that these leave out a crucial element of mobility: time. 


\section{Fragments of legal storytelling}

Most of the 41 children of our sample had first arrived in Finland as unaccompanied asylum seekers and had been granted international protection. In other words, they could be labelled 'anchor children' in the anti-immigration rhetoric.

One of our key findings is that the reported backgrounds of the families are strikingly alike. The children were mostly teenagers, but six of them were under ten years old upon arrival. One of the families was originally from Iraq, but the rest were Somali nationals, typically from the war-ridden capital, Mogadishu. The families were large, with an average of seven family members in each application. Half of the cases also included foster siblings, thus fitting into another momentous debate around the turn of the decade on 'the phenomenon of foster children'. The 'profile' of applicants is thus consistent with the most mistrusted forms of family migration.

The similarities of the cases do not derive solely from the backgrounds of the applicants, however. Rather, they stem from the established forms of investigation, more precisely from the questions posed and the details focussed on or fabricated. The decisions certainly also reflect the logic applied by the authorities in 'legal storytelling' (Kruse 2016). Not only are the arguments of the decisions strikingly similar, but the appeals also focus on similar issues from one case to another. In fact, the cases sponsored by children stand out from the rest because of the evident reduction of the arguments and evidence. This, in turn, clearly reflects the perceived problematic of applications sponsored by children.

Beyond the technicalities, the scattered pieces of evidence are put into legal format by grounding the arguments in the provisions of relevant legislation. Because of the extended times of processing, however, the relevant legislation has in many cases been amended during the procedure. Of particular significance are the aforementioned amendments of 2010 (549/2010) that clearly demonstrate the consequences of increased suspicion. The arguments related to the child's best interest, that is, the ones that could and should loom large in these cases, are largely glossed over or at best only given a marginal role.

\section{'Time is on our side': the temporalities of imagined immutability}

A geneticist pointed out in an interview that he and his colleagues 'do not want to know what has happened before the sample arrives in the lab or what happens thereafter'. Conversely, the 'before' is of paramount importance in the decisions. Our material illustrates the unfolding of two conflicting, but closely interwoven temporalities: the bureaucratic time of control and the migrant time of waiting (Andersson 2014b; see also Khosravi 2007, 2010; Feldman 2011; Cabot 2012; Andersson 2014a).

The predicament of bureaucratic time is evidenced by the considerable backlog of applications filed by Somalis that was 'cleared' in 2014. Many of the applications of our sample were submitted during the years of congestion, extended processing times and legislative restrictions. The imagined immutability of proof does not take the passage of time and inevitable transformations into account, but rather negates them.

In the case of DNA analysis, the samples are swiftly sent from the embassies to the laboratory via diplomatic mail, and the reports are forwarded to the Finnish Immigration Service without delay. For the people waiting for the process and decisions, in contrast, 
there is no express track. Instead, bureaucratic time prolongs periods of separation, and often efficiently obstructs the coming together of kin.

In the opening vignette of our article, the police officer summed up the situation from the point of view of the bureaucrats: 'Time is on our side.' She was referring to the fact that because of the prolonged duration of the process, the interviewees' tactics are curtailed; people can forget what has been said: the questions asked and the answers given. However, this remark can be read in a more extended sense, too. The applicants' attorneys often stressed that proceedings had clearly exceeded nine months, the set maximum time for family reunification proceedings. Numerous cases had been pending for two to three years. Hence, the decisions violated the principles of Article 10 of the Convention of the Rights of the Child which states that the applications for family reunification 'shall be dealt by State Parties in a positive, humane and expeditious manner'. Similarly, pursuant to Section 6(3) of the Finnish Aliens Act, '[m] atters concerning minors shall be processed with urgency'. No justification has been given in the files for the extended time. Quite the contrary: it is sometimes bluntly stated that exceeding the time limits does not justify a favourable outcome.

Time is certainly a particularly critical factor for teenagers. On the basis of medical age assessment (in Finland) or appearance (abroad), a youth can be said to have aged out, thereby losing the right to family reunification. ${ }^{4}$ Interestingly, in some cases the Court also expands the relevant age phase by arguing that the sponsor is approaching the age of 18 years, has started her studies or is approaching marital age and no longer needs a guardian. Family reunification is no longer in the best interest of the child. On the contrary, it is believed to hinder her integration (Kuusisto-Arponen 2016).

\section{The conditional time of migration}

Let us return to A's case. At the time of the ruling, five years had passed since his arrival in Finland. The decision details particulars of his father B's past before his son was born. G, one of B's brothers, already lived in Finland and had repeatedly filed applications for family reunification for his siblings. When $B$ was en route to Ethiopia with his siblings for the interview at the Finnish Embassy, the bus exploded, killing two of his brothers. $G$ had sent money to his family members who subsequently lived illegally in Ethiopia for years. When $\mathrm{G}$ could no longer afford to provide for them, the kindred had decided to send $\mathrm{A}$ to his uncle $G$ in Finland. The court decision relates that $A$ talked to his mother on the phone 'once a month for at least five minutes' but no longer spoke Somali so the brief dialogue had to be translated by his uncle. These details bring into relief many complications in family reunification. The trajectories of mobility are permeated with varied uncertainties, dangers and ruptures, in the midst of which people can lose contact, disappear or die. In these circumstances, family ties cannot remain immutable or easily decipherable. However, coping depends on the persistent mobilisation of kinship ties.

In contrast to measurable and abstract bureaucratic time, or the 'time of control', another temporality or 'migrant time' unfolds with unforeseen consequences (Andersson 2014b). The latter starts with the departure of the future sponsor and extends beyond the decisions. ${ }^{5}$ Well before the filing of the application for family reunification, the children have to face the perils of 'illegal' travelling which is, according to our interlocutors, usually organised by traffickers. Next, he or she must wait for the processing of the 
asylum application. Unaccompanied minors have usually been granted some form of international protection, but only after a range of investigations that include, for example, the tracing of guardians, medical age assessment and language analysis.

The appeals are testimony to the perils. In half of the cases sponsored by minors, at least one family member had died or been killed before or during the process, and in three cases at least one family member had disappeared. The people assisting the sponsors in NGOs and law firms often refer to the dire circumstances. A social worker had witnessed a case where a father had submitted an application to reunite with his nine children who were left behind in Africa. When the decision finally arrived, only two of them were still alive. She pointed out that this was not a singular case:

Such instances happen all the time, people just die along the way. The wait is not like sitting idly on a couch. A lot of people die on the way: of hunger, war, for all kinds of reasons.

Family reunification can be hindered at many stages before actual decision-making. Not only is the submitting of applications demanding but the tracking of guardians can also become an insurmountable obstacle. The figure of children as anchors for large families is a convenient image but clearly erroneous. It has been estimated that about a half of the unaccompanied minors did not get a single family member to Finland in the first decade of this century, that is, before the restrictive amendments of the Aliens Act came into force in 2010 (Pakolaisneuvonta 2011). Since then, the prospects have dimmed further (see Kuusisto-Arponen 2016). An experienced solicitor exclaimed that in many cases the kin cannot even be traced:

This mentality behind the notion of 'anchor children' is senseless and utterly cruel - at this very moment we are receiving children from horrendous conditions, for example from the Democratic Republic of the Congo, Angola or Somalia - these children have nobody anywhere, at least no kin alive.

\section{The making of facts}

An immigration lawyer encapsulated the current tendencies in the use of DNA testing as follows: 'DNA was at the centre when it was first applied; it was the definitive factor and it was easy and comfortable for all because it was so clear'. Nowadays, she continued, a negative decision can be based on other reasons, 'on grounds that can be made-up'. The 'truth' built on minutiae is far removed from the complications in family life of people on the move. In contrast to the image of bounded families, continuation is built on the inevitable 'thickening and thinning' of relatedness (Carsten 2013), especially in times of prolonged crisis. The documents, narratives of experts and Court decisions bring to the fore the quest for truth via the making of facts that are allegedly objective enough to provide evidence of the aforementioned 'genuine and permanent family life'.

For this purpose, all family members, including children, are heard separately in interviews that take several hours. The sponsor has already been asked about his or her family ties upon entering Finland, and the subsequent interviews take place after lengthy intervals, when circumstances may have changed considerably and recollections faded. Time is definitely not on their side. The details that make a difference are systematically created, which is, according to an official, challenging in the 'Somali context' where: 
The children often cannot attend school regularly, the parents may not have jobs, and the quotidian life of the family can be scattered, in a way. It is very difficult to find markers with which we could piece together an image of family life. And they may all be illiterate with a tenuous conception of time. [compared to ours]

She tellingly referred to 'markers', thereby extending the vocabulary and logic of DNA analysis to the evidence created in the narrative form. Further, she acknowledged that the details can be far-fetched in terms of actual family life. She also implied that capturing the basic indicators is difficult: 'Well, we are sometimes really in trouble, and expertise is called for evaluating what kind of questions to ask and how to formulate them'. The particularities of family life are not mobile in the sense of translatability; it is difficult to find 'markers' that would make sense both to the interviewees and to the decision-makers.

The Court's decisions display how the legal narrative is fabricated through details that only marginally relate to family life in the sense of commitment or care. For the family to count as a family, legally speaking, there must be little contradiction in recounting the details. The minutiae created through precise questions are indeed good markers, concrete enough to trigger inconsistencies between the interviewees, and, by the same token, to provide evidence of alleged fraud. In this sense, the interview evidence runs parallel to the logic of DNA analysis which works as a 'biological lie detector' (see Weiss 2011; Hall and Naue 2015). The questions asked dwell on details such as schooling, livelihood, abodes, sleeping arrangements, electricity, water, and the division of labour within the household - all facts that are mutable, especially during prolonged crisis and forced mobility. The questions related to dwellings are, despite and because of their materiality, problematic: families often have to sell their houses to finance the sponsor's emigration, and the rest of the family also has to move on, for example, to be near a Finnish Embassy for the application, interviews and DNA testing. The children, especially, may be confused when asked about the continually changing abodes. A Finnish Somalian man explained the contradictions in the interviews of his children by saying that the family had moved house four times, fleeing and fleeing'.

It is particularly striking that the reasons for the sponsor's departure from the homeland are re-examined to determine whether it had indeed been involuntary. Hence, the questions asked also concern traumatic events like homicides and disappearances. If it is argued that the threat has not been convincingly proved, it is concluded that the sponsor's kin have tried to circumvent the provisions on entry. In other words, the sponsor was sent off as an anchor child in the hope of eventual family reunification. An oft-repeated phrase in rejections states that the parents had sent the child off 'although they must have known that continuing family life in Finland was uncertain'. Therefore, with this move, the family tie had ceased to exist. Alternately, it is concluded that there had not been sufficiently stable family life in the first place.

The Finnish Immigration Service seems to prefer questions that can be answered as precisely as possible. Despite the complications mentioned in the quote above, the interviews often focus on details that can be formulated in terms of numbers, such as dates or the number of trees, notwithstanding illiteracy and extreme youth. In one appeal, it was specified that one of the interviewees 'was only ten years old at the time of the hearing, and it was written down in the minutes that he did not understand the difference between a week, a month and a year' (08329/11/3101). Giving exact answers to the questions despite uncertainty is, according to a lawyer, quite common. Therefore, she and her 
colleagues emphasise to their clients, 'If you are not sure about something, say it'. The appeals often argue that the inaccuracies were irrelevant. In one appeal (03299/13/ 1301), one such inconsistency was raised concerning the availability of electricity. The child sponsoring the application had said that the electricity went off in the evenings, but in reality, 'his mother may merely have turned off the lights'. While the quest for precise 'truth' motivates the hearings, there is no documentation on the actual situation, let alone on the complications like fear, trauma, misunderstanding, translation errors or attrition. According to a Somali woman whose child had 'failed' the interview, the questions 'come with a twist'.

The proof is, at least implicitly, also believed to be mobile in the sense of legibility and translatability, despite the pronounced social and cultural differences spanned. The facts created should ideally prove that family life, notwithstanding perceived strangeness, had been close enough to the idea of an acceptable family. The narrative has to resonate with the perceived cultural frameworks of the decision-makers (Carver 2014, 275). Identification is the basis both for rejections and for belief (Fassin 2005; Fassin and D'halluin 2005; Kelly 2012). However, in the decisions over people with a refugee background, in comparison with the marriage migration of others (see Pellander 2014), the emphasis is on minor material details. It is often concluded, on the basis of minor inconsistencies, that the applicants have not led a stable family life together. This, in turn, leads to a robust conclusion: '[A]nd therefore they are not family members in the sense laid down in Section 37 of the Aliens Act'- as if the criteria for true family ties were clearly defined in the legislation.

What is the role of the DNA analysis in this maze of evidence? It may paradoxically be more comprehensible than the intricate and suspect details of family life. The solicitors and the representatives of NGOs we interviewed were convinced that DNA testing is the applicants' right rather than an obstacle. According to one lawyer, with DNA analysis 'one can fend off the minor issues of credibility'. Neither do the people concerned see it as a major problem, quite the contrary. In one interview, a Finnish Somalian man thrice repeated a simple question: 'Why is DNA not enough?' Our material provides evidence that DNA testing is seen as a first and most obvious $t$ solution by the applicants and their solicitors. This is evident in the Court decisions as a whole: the most typical reason for being included in our sample was that DNA testing had been appealed for. The conundrum is further highlighted by the fact that in one fifth of the 253 cases DNA analysis had already verified the claimed family ties but the application was rejected because the existence of true family ties was still in doubt (see Halme-Tuomisaari, Tapaninen, and Aunela n.d.). Of the 41 cases analysed in this article, 8 had been rejected despite proven biological ties.

\section{Conclusions}

The term 'anchor child' singles out the applications sponsored by minors as a suspect form of immigration, thereby emphasising that the investigations must dig up the truth efficiently, though in the name of the best interest of the child. For this purpose, DNA analysis offers a convenient, widely accepted tool. We have shown, however, that genetic kinship verified through DNA testing is not the answer, at least for the applicants themselves. The vague idea of 'genuine families' complicates the verification of relatedness. Nevertheless, 
we have argued that DNA analysis, the immutable mobile par excellence, in the form of genetic markers, provides a model for objective and accurate proof in general. Therefore, we believe that the 'markers' of family life referred to by the official above did not derive from a mere terminological coincidence; biotechnological information and detailed narrative evidence are continuously apposed. Consequently, in practice, acceptable families are defined through the meticulous investigations.

The investigations driven by the quest for truth strive to seek proof that is, as Latour (1986) put it, immutable, combinable and mobile. Yet the proof is built on fragmented, snapshot-like inscriptions that are far removed from time and its contingencies. The imagined immutability stands in stark contrast to the unpredictable trajectories of people on the move. By juxtaposing the technologies of doubting with the temporalities of migration, our analysis sheds light on the fundamental contrast between the immutable and the contingent. Temporalities take many forms. First, the duration of the process not only suspends but also obstructs family reunification, especially for children who can age out before the decision. It is commonly argued that family ties have been cut with the passing of time. Yet this is partly due to the slow unfolding of bureaucratic time.

Second, in oral hearings time figures in two ways. Specific points of time are a recurrent theme in questions. Further, the persistent questions aiming at precision are difficult to answer coherently after long separations and if the interviewees are not familiar with chronological time. The pursuit of objectivity pinpoints minutiae, typically material details even though these may have been forgotten, altered or irrelevant. Family life and households are never immutable but set in the complicated dynamics of kinship and constant change. For people with a refugee background, providing credible evidence is difficult because of the circumstances under which they fled. Whatever is measurable and disprovable seems to count the most. The Court often concludes that DNA testing would not yield significant results because the other criteria are not met. Simultaneously, the best interest of the child is not considered with similar thoroughness to the alleged use of children as 'instruments of immigration'.

A third form of temporality inheres in the way the very term family reunification denotes a nexus between the lived past and the future of aspiration. The trope 'anchor child' encapsulates the suspicion of people's intentions and tactics. Paradoxically, the reasons that justified the need for protection are often re-examined in the context of family reunification, and are often read as an attempt to circumvent the provision of entry.

Fourth, time infuses the changes in policing that are both reflected in, and established by, the Court decisions. There has been a surprisingly consistent development of policies concerning the problem of 'anchor children' over more than a decade. The Court decisions we examined clearly echo and substantiate the arguments of the Administrative Committee in 2004. However, the principles applied in the processes have undergone constant legislative and administrative changes that have made family reunification increasingly difficult, especially for people with a refugee background and for underage sponsors. Lately this tendency has intensified. When the European 'refugee crisis' of 2015 reached Finland, bringing a record number of unaccompanied minors seeking asylum, the government swiftly launched a project to tighten the criteria of family reunification. The recent amendments of the Aliens Act that came into force on July 2016 are beyond the scope of this article, but we are convinced that they are part of this continuum. In short, the 
amended Aliens Act states that the sponsors should have (a considerable) 'stable income' unless the application is filed within three months of the sponsor receiving the residence permit. ${ }^{6}$ Hence, the passing of time has become more critical than before. Few can get even one guardian to Finland. To succeed, people must have exceptional economic and social resources, which brings the Finnish system close the German one, albeit with a crucial difference: in Germany DNA analysis functions as a trump card in the search for credibility (Heinemann and Lemke 2015) while in Finland DNA evidence is trumped by a range of other factors. On the whole, the best interest of the child has retreated further as a principle guiding policing.

\section{Acknowledgements}

The authors want to thank the following people for their comments: the two anonymous reviewers, Ilpo Helén, Jaana Palander, and a solicitor who prefers to remain anonymous.

\section{Disclosure statement}

No potential conflict of interest was reported by the authors.

\section{Funding}

This work was supported by the Academy of Finland under grant 135266 and by the Kone Foundation

\section{Notes}

1. The term 'anchor child' was first introduced by a politician in 2006 , and was soon captured as a keyword by the media (Horsti and Pellander 2015). It must be emphasized, however, that it is not used by the migration administration (but see EMN 2009, 2011). In this article, we refer to it to highlight how a single moralising term encapsulates suspicion. Therefore, we will hereafter omit the quotation marks.

2. In Finland's report on irregular migration (EMN 2011) both anchor children and foster children are singled out as specific problems.

3. This drop testifies to the consequences of the new demands on administrative efficiency. Following the coming into force of the Act on the Promotion of Immigrant Integration (1386/ 2010), even the filing of applications takes more time and is more expensive and even impossible for many.

4. However, in 2015 the Supreme Administrative Court reinterpreted one case concerning ageing out during the prolonged process and revoked it (KHO: 2015:26), which, as a precedent case, should have consequences for subsequent decisions.

5. The time line of the process can be exemplified by a case of a Somalian girl (03299/3101). She escaped from Somalia in 2009, at the age of thirteen. Her guardians, mother and stepfather, soon had to flee from their home, too. In May 2010, she was granted the status of secondary protection, and in September she filed an application for family reunification to be reunited with her parents. It took another year before she was interviewed by the police, and her parents were not interviewed in the Finnish Embassy of Addis Ababa until May 2012. DNA analysis had verified the tie between the mother and the daughter. The Finnish Immigration Service rejected the applications in December 2012 but the decision was communicated only after four months. The Court rejected the appeal in April 2014. The process as a whole had taken five years, and meanwhile she had turned eighteen. The duration of this process was long but not exceptional. 
6. The only exception is made in the above-mentioned Section 52. that is, when children apply for family reunification with their sibling who is an unaccompanied minor with a residence permit on compassionate grounds.

\section{ORCID}

Anna-Maria Tapaninen (D) http://orcid.org/0000-0003-1484-0775

\section{References}

Aas, K. F. 2006. “The Body Does Not Lie': Identity, Risk and Trust in Technoculture.” Crime, Media, Culture: An International Journal 2 (2): 143-158.

Andersson, Ruben. 2014a. "Hunter and Prey: Patrolling Clandestine Migration in the Euro-African Borderlands.” Anthropological Quarterly 87 (1): 119-149.

Andersson, Ruben. 2014b. "Time and the Migrant Other: European Border Controls and the Temporal Economics of Illegality." American Anthropologist 116 (4): 795-809.

Cabot, Heath. 2012. "The Governance of Things: Documenting Limbo in the Greek Asylum Procedure." PoLAR: Political and Legal Anthropology Review 35 (1): 11-29.

Cabot, Heath. 2014. On the Doorstep of Europe: Asylum and Citizenship in Greece. Philadelphia: University of Pennsylvania Press.

Carsten, Janet. 2013. "What Kinship Does - and How." HAU: Journal of Ethnographic Theory 3 (2): 245-251.

Carver, Natasha. 2014. "Displaying Genuineness: Cultural Translation in the Drafting of Marriage Narratives for Immigration Applications and Appeals." Families, Relationships and Societies 3 (2): 271-286.

Cwerner, Saulo B. 2010. “The Times of Migration.” Journal of Ethnic and Migration Studies 27 (1): $7-36$.

Dove, Edward S. 2013. "Back to Blood: The Sociopolitics and Law of Compulsory DNA Testing of Refugees.” University of Massachusetts Law Review 8: 466.

EMN (European Migration Network). 2009. “Ad Hoc Query on Conducting Other Investigation (Using a DNA Test) in Family Reunification.” https://ec.europa.eu/home-affairs/sites/ homeaffairs/files/what-we-do/networks/european_migration_network/reports/docs/ad-hocqueries/family-reunification/150._emn_ad-hoc_query_conducting_other_investigation_using a_dna_test_in_family_reunification_case_en.pdf.

EMN (European Migration Network). 2011. Practical Measures for Reducing Irregular Migration. Finland 2011. Accessed January 12, 2017 http://www.emn.fi/files/533/Practical_Measures_for_ Reducing_Irregular_Migration_Finland_FINAL_EN.pdf.

EMN (European Migration Network). 2012. Misuse of the Right to Family Reunification - Marriages of Convenience and False Declarations of Parenthood. Accessed January 10, 2017. http://www. refworld.org/docid/51b895af4.html.

EMN (European Migration Network). 2016. EMN Ad Hoc Query on Checking Identity and Family Relationships in Case of Family Reunification with a Beneficiary of International Protection. https://ec.europa.eu/home-affairs/sites/homeaffairs/files/what-we-do/networks/european_ migration_network/reports/docs/ad-hoc-queries/ad-hoc-queries-2016.1074_nl_checking_ identity_and_family_relationships.pdf.

Esbenshade, Jill. 2010. “An Assessment of DNA Testing for African Refugees.” Immigration Policy Center, American Immigration Council, Washington, DC. http://scholar.google.com/scholar? cluster $=6055339037789908199 \& \mathrm{hl}=$ en\&oi=scholar.

Fassin, Didier. 2005. "Compassion and Repression: The Moral Economy of Immigration Policies in France.” Cultural Anthropology 20 (3): 362-387. 
Fassin, Didier, and Estelle D'halluin. 2005. "The Truth from the Body: Medical Certificates as Ultimate Evidence for Asylum Seekers.” American Anthropologist 107 (4): 597-608.

Feldman, Gregory. 2011. "If Ethnography Is More than Participant-Observation, Then Relations Are More than Connections: The Case for Nonlocal Ethnography in a World of Apparatuses." Anthropological Theory 11 (4): 375-395.

Finnish Immigration Service. 2008. "DNA Analysis Has Unified a Record Number of Immigrant Families.” http://www.migri.fi/for_the_media/bulletins/press_releases/press_releases/1/0/dna_ testing_has_united_a_record_number_of_immigrant_families_13968.

Gibb, Robert, and Anthony Good. 2014. "Interpretation, Translation and Intercultural Communication in Refugee Status Determination Procedures in the UK and France." Language and Intercultural Communication 14 (3): 385-399.

Good, Anthony, Daniela Berti, and Gilles Tarabout. 2015. "Introduction: Technologies of Doubt in Law and Ritual." In Of Doubt and Proof: Ritual and Legal Practices of Judgment, edited by Daniela Berti, Anthony Good, and Gilles Tarabout, 1-18. Farnham: Ashgate.

Griffiths, Melanie. 2014. "Out of Time: The Temporal Uncertainties of Refused Asylum Seekers and Immigration Detainees." Journal of Ethnic and Migration Studies 40 (12): 1991-2009.

Griffiths, Melanie, Ali Rogers, and Bridget Anderson. 2013. "Migration, Time and Temporalities: Reviews and Prospect.” COMPAS Resources Paper, March 2013.

Hage, Ghassan. 2009. "Waiting out the Crisis: On Stuckedness and Governmentality." In Waiting, edited by Ghassan Hage, 97-106. Melbourne: Melbourne University Press.

Hall, Kevin, and Ursula Naue. 2015. “Austria: DNA Profiling as a Lie Detector.” In Suspect Families: DNA Analysis, Family Reunification and Immigration Policies, edited by Torsten Heinemann, Ilpo Helén, Thomas Lemke, Ursula Naue, and Martin G. Weiss, 55-78. Farnham: Ashgate.

Halme-Tuomisaari, Miia, Anna-Maria Tapaninen, and Hilja Aunela. n.d. Where's the Well: DNA Evidence, Personal Narratives and Unpredictability in Finnish Family Reunification. Revised manuscript resubmitted to Migrations.

HaVM (Hallintovaliokunta) 4/2004). 2004. Hallintovaliokunnan mietintö. https://www.eduskunta. fi/FI/vaski/mietinto/Documents/havm_4+2004.pdf.

Heinemann, Torsten, Ilpo Helén, Thomas Lemke, Ursula Naue, and Martin G. Weiss, eds. 2015. Suspect Families: DNA Analysis, Family Reunification and Immigration Policies. Farnham: Ashgate.

Heinemann, Torsten, and Thomas Lemke. 2013. "Suspect Families: DNA Kinship Testing in German Immigration Policy.” Sociology 47 (4): 810-826.

Heinemann, Torsten, and Thomas Lemke. 2014. "Biological Citizenship Reconsidered." Science, Technology, \& Human Values 39 (4): 488-510.

Heinemann, Torsten, and Thomas Lemke. 2015. "Germany: The Geneticisation of the Family." In Suspect Families: DNA Analysis, Family Reunification and Migration Policies, edited by Torsten Heinemann, Ilpo Helén, Thomas Lemke, Ursula Naue, and Martin G. Weiss, 13-32. Farnham: Ashgate.

Heinemann, Torsten, Ursula Naue, and Anna-Maria Tapaninen. 2013. "Verifying the Family? A Comparison of DNA Analysis for Family Reunification in Three European Countries (Austria, Finland and Germany).” European Journal of Migration and Law 15 (2): 183-202.

Helén, Ilpo. 2014. "Biological Citizenship Across the Borders: Politics of DNA Profiling for Family Reunification.” Distinktion: Scandinavian Journal of Social Theory 15 (3): 343-360.

Helén, Ilpo, and Anna-Maria Tapaninen. 2013. "Closer to the Truth: DNA Profiling for Family Reunification and the Rationales of Immigration in Finland." Nordic Journal of Migration Research 3 (3): 153-161.

Holland, Emily. 2014. "Moving the Virtual Border to the Cellular Level: Mandatory DNA Testing and the U.S. Refugee Family Reunification Program." California Law Review 99 (6): 1635-1682.

Horsti, Karina, and Saara Pellander. 2015. "Conditions of Cultural Citizenship: Intersections of Gender, Race and Age in Public Debates on Family Migration." Citizenship Studies 19 (6-7): 751-767.

Kelly, Tobias. 2012. "Sympathy and suspicion: torture, asylum, and humanity." Journal of the Royal Anthropological Institute 18 (4): 753-768. 
Kelly, Tobias. 2015. “Afterword.” In Of Doubt and Proof: Ritual and Legal Practices of Judgement, edited by Daniela Berti, Anthony Good, and Gilles Tarabout, 183-192. Farnham: Ashgate.

Khosravi, Shahram. 2007. "The 'Illegal Traveller: An Auto-Ethnography of Borders." Social Anthropology 15 (3): 321-334.

Khosravi, Shahram. 2010. 'Illegal'Traveller: An Auto-Ethnography of Borders. Basingstoke: Palgrave Macmillan.

Kruse, Corinna. 2016. The Social Life of Forensic Evidence. Oakland: University of California Press.

Kuusisto-Arponen, Anna-Kaisa. 2016. "Perheettömiksi suojellut: yksin tulleiden alaikäisten oikeus perheeseen." In Perheenyhdistäminen: kuka voi saada perheen Suomeen, kuka ei ja miksi? edited by Outi Fingerroos, Anna-Maria Tapaninen, and Marja Tiilikainen, 89-110. Tampere: Vastapaino.

La Spina, Encarnación. 2012. "DNA Testing for Family Reunification in Europe: An Exceptional Resource?” Migraciones Internacionales 6 (3): 39-74.

Latour, Bruno. 1986. "Visualization and Cognition: Thinking with the Eyes and Hands." Knowledge and Society 6 (6): 1-40.

Maahanmuuttovirasto. 2013. Oleskelulupa perhesiteen perusteella. Unpublished memorandum 13.5.2013. Helsinki: Maahanmuuttovirasto.

Maahanmuuttovirasto. 2014. "Myönteiset ja kielteiset ratkaisut ensimmäisiin oleskelulupiin 1.1.2013 - 31.12.2013.” Accessed March 15, 2017. http://www.migri.fi/download/44456_ Ratkaisut_hakuperusteittain_myont_kielt-1.1.-31.5.2013.pdf?520a5d69c55bd488.

Maahanmuuttovirasto. 2017. "Toteutuneet keskimääräiset käsittelyajat vuorokausissa." Accessed November 22, 2017. http://www.migri.fi/nain_palvelemme/kasittelyajat/keskimaaraiset_ kasittelyajat_aikaisempina_vuosina.

M'charek, Amâde. 2000. "Technologies of Population: Forensic DNA Testing Practices and the Making of Differences and Similarities." Configurations 8 (1): 121-158.

Murdock, Tera Rica. 2008. "Whose Child Is This: Genetic Analysis and Family Reunification Immigration in France." Vanderbilt Journal of Transnational Law 41: 1503.

Pakolaisneuvonta. 2011. "Alaikäisten yksintulleiden perheenyhdistäminen." http://www. pakolaisneuvonta.fi/index_html?lid=141\&lang=suo.

Pellander, Saara. 2014. ““'An Acceptable Marriage”.” Journal of Family Issues 36 (11): 1472-1489.

Scott, James C. 1999. Seeing Like a State: How Certain Schemes to Improve the Human Condition Have Failed. New Haven, CT: Yale University Press.

Taitz, J., J. E. M. Weekers, and D. T. Mosca. 2002. "The Last Resort: Exploring the Use of DNA Testing for Family Reunification.” Health and Human Rights 6 (1): 20-32.

Tapaninen, Anna-Maria, and Ilpo Helén. 2015. “Finland: Securing Human Rights, Suspecting Fraud.” In Suspect Families: DNA Analysis, Family Reunification and Immigration Policies, edited by Torsten Heinemann, Ilpo Helén, Thomas Lemke, Ursula Naue, and Martin G. Weiss, 33-54. Farnham: Ashgate.

UNHCR (UN High Commissioner for Refugees). 2008. "UNHCR Note on DNA Testing to Establish Family Relationships in the Refugee Context." http://www.refworld.org/docid/ 48620c2d2.html.

van der Ploeg, Irma. 1999. “The Illegal Body: 'Eurodac' and the Politics of Biometric Identification.” Ethics and Information Technology 1 (4): 295-302.

Villiers, Janice D. 2010. "Brave New World: The Use and Potential Misuse of DNA Technology in Immigration Law.” Boston College Third World Law Journal 30 (2): 239-271.

Weiss, Martin G. 2011. "Strange DNA: The Rise of DNA Analysis for Family Reunification and Its Ethical Implications." Genomics, Society and Policy 7 (1). doi:10.1186/1746-5354-7-1-1.

Whyte, Zachary. 2015. "In Doubt: Documents as Fetishes in the Danish Asylum System." In Of Doubt and Proof: Ritual and Legal Practices of Judgment, edited by Daniela Berti, Anthony Good, and Gilles Tarabout, 141-162. Farnham: Ashgate. 